ARAŞTIRMA / RESEARCH

\title{
The impact of objective nutritional indexes on in-hospital mortality in Covid-19 infection
}

Covid-19 enfeksiyonunda objektif nutrisyonel indekslerin hastane içi mortaliteye etkisi

Arafat Yıldırım1D, Özge Özcan Abacıoğlu1D, Mehmet Cenk Belibağlı2 (D)

${ }^{1}$ Health Sciences University, Adana Research and Training Hospital, Department of Cardiology, ${ }^{2}$ Department of Family Medicine, Adana, Turkey

\begin{abstract}
Purpose: The effect of nutritional status on in-hospital mortality in patients with coronavirus disease 2019 (COVID-19) is unclear. We aimed to analyze the relationship between nutritional status score (CONUT) and prognostic nutritional index (PNI) and in-hospital mortality in COVID-19 infection.

Materials and Methods: We included 187 patients with COVID-19 between 11 March-10 May 2020. The CONUT and PNI scores were calculated using the laboratory results. The groups were divided into survival and in-hospital mortality

Results: The mean age of the patients was $66.2 \pm 15.8$ years $(55.3 \%$ male). The mortality rate was $20.8 \%(n=39)$. The median PNI scores was significantly lower and the median CONUT score was significantly higher in the mortality group. Multivariate regression analysis showed that PNI and CONUT were independent predictors of mortality. ROC curve analyses showed that CONUT had a better performance than PNI to predict in-hospital mortality. Conclusion: In COVID-19 patients, CONUT and PNI scores were independently associated with in-hospital mortality, with CONUT presenting a better performance than PNI.
\end{abstract}

Keywords:. Coronavirus disease 2019, CONUT, PNI

\section{Öz}

Amaç: Koronavirüs hastalığı 2019 (COVID-19) tanısı nedeniyle yoğun bakım ünitelerinde yatan hastaların beslenme durumunun hastane içi mortaliteye etkisi belirsizdir. Çalışma, COVID-19 enfeksiyonu hastalarında iki objektif nutrisyonel indeksler olan controlling nutritional status score (CONUT) ve prognostic nutritional indeksi (PNI) nin hastane içi mortalite ilișkisini analiz etmeyi amaçladı.

Gereç ve Yöntem: Çalışmaya 11 Mart-10 Mayıs 2020 tarihleri arasında yoğun bakım ünitelerinde yatan 187 COVID-19 hastası dahil edildi. Demografik ve klinik verileri kaydedildi. CONUT ve PNI skorları laboratuvar sonuçlarından hesaplandi. Hastalar mortalite grup ve ve non-mortalite grup olmak üzere iki gruba ayrildı.

Bulgular: Hastaların ortalama yaşı $66.2 \pm 15.8$ yll (\% 55,3 erkek), ölüm oranı \% 20,8 ( $n=39)$ idi. Mortalite grubunda Medyan PNI skorları anlamlı olarak daha düşük ve medyan CONUT skorları anlamlı olarak daha yüksek belirlendi. Çok değişkenli regresyon analizinde, PNI ve CONUT un mortalite ile bağımsız olarak ilișkili olduğunu belirlendi. Ayrıca ROC eğrisi analizlerinde, CONUT un hastane içi mortaliteyi tahmin etmede, PNI'den daha iyi bir performansa sahip olduğunu belirlendi.

Sonuç: COVID-19 hastalarında, CONUT ve PNI skorlarının hastane içi mortalitede bağımsız prediktörler olduğunu ve CONUT"un PNI'dan daha iyi bir performansa sahip olduğu belirlenmiștir.

Anahtar kelimeler: Koronavirüs hastallğı 2019, CONUT, PNI

Yazışma Adresi/Address for Correspondence: Dr. Arafat Yıldırım, Health Sciences University, Adana Research and Training Hospital, Department of Cardiology, Adana, Turkey Email: arafatdr@hotmail.com Geliş tarihi/Received: 25.01.2021 Kabul tarihi/Accepted: 01.04.2021 Çevrimiçi yayın/Published online: 20.05.2021 


\section{INTRODUCTION}

Coronavirus disease 2019 (COVID-19) is an infectious respiratory disease affecting humans caused by severe acute respiratory syndrome coronavirus 2 (SARS-CoV-2) $)^{1,2}$. Most cases experience the virus with no (asymptomatic) or mild symptoms, including fever, coughing, and dyspnea ${ }^{3,4}$. However, in some cases, the disease progresses into a severe form and result in pneumonia and multiple organ failure ${ }^{5}$. The initial data from China, where the disease was believed to be originated, showed that $6 \%$ of the cases required intensive care unit (ICU), whereas Europe and the USA data is higher ${ }^{5,6}$. The studies indicated that in COVID-19 cases, the male gender, older age, coronary heart disease, hypertension (HT), and diabetes mellitus (DM) were associated with mortality ${ }^{2-4}$. The risk of mortality was shown to increase with age. The mortality rate for people younger than 50 years was $0.5 \%$, and the rate was shown to rise to $8 \%$ for those aged 70 and over 7 .

Up to date, many laboratory parameters, including high sensitivity cardiac troponin I (hs-c'TnI), brain natriuretic peptide $(\mathrm{BNP})$, lactate dehydrogenase $(\mathrm{LDH})$, myoglobin, creatinine, urea, alanine aminotransferase (ALT), aspartate aminotransferase (AST), and total bilirubin was shown to be related with mortality in patients with COVID-198-11. Also, increased D-dimer, CRP, ferritin levels, and lymphopenia have emerged as independent risk factors for poor outcomes, including death ${ }^{12,13}$. Additional laboratory markers and blood count parameters have also been associated with poor prognosis due to possible links with the thrombosis mechanism ${ }^{13}$.

In many studies, the nutritional condition of patients with different diseases was associated with mortality ${ }^{14-17}$. Therefore, in addition to the laboratory parameters and clinical risk factors, the nutritional condition of the COVID-19 patients might be used to predict mortality.

Yet, to the best of our knowledge, there are no studies available that evaluated the relationship between the nutritional condition of COVID-19 patients and in-hospital mortality. Thus, the study aimed to analyze the association of the two objective nutritional indexes, controlling nutritional status score (CONUT) and prognostic nutritional index (PNI) with in-hospital mortality of COVID-19 cases. Besides, the two indexes were compared for superiority in predicting mortality.

\section{MATERIALS AND METHODS}

The study was approved by the Ministry of Health Clinical Research Ethics Committee of our country and our hospital Adana City Training and Research Hospital local Clinical Research Ethics Committee (873-57 / 20.05.2020). For the study, the data of all patients who were hospitalized with symptoms and laboratory or radiological findings of COVID-19 at our tertiary center serving as a pandemic hospital between 11 March 2020 and 10 May 2020 were recorded from the hospital digital recording system and patient files. In the study of Ai et al. published in August, chest CT findings were more sensitive than PCR positivity ${ }^{17}$.

Venous blood samples of the patients were taken when they were admitted to the intensive care unit. Baseline blood sample results and the routine examination data, including arterial blood gas, respiration rate, systolic and diastolic blood pressure, temperature, heart rate, were recorded. Also radiologic findings, ongoing treatment and clinical outcomes were noted. Patients with missing blood parameters or demographic characteristics like height, weight, respiratory rate, and blood gas measurement in the patient files were excluded from the study.

Table 1. CONUT score calculation

\begin{tabular}{|l|l|l|l|l|}
\hline Parameters & Normal & Light & $\begin{array}{l}\text { Modera } \\
\text { te }\end{array}$ & Severe \\
\hline $\begin{array}{l}\text { Serum } \\
\text { albumin } \\
\text { (g/dL) }\end{array}$ & $\geq 3.50$ & $\begin{array}{l}3.00- \\
3.49\end{array}$ & $\begin{array}{l}2.50- \\
2.99\end{array}$ & $<2.50$ \\
\hline Score & 0 & 2 & 4 & 6 \\
\hline $\begin{array}{l}\text { Total } \\
\text { lymphocyte } \\
\text { count }\end{array}$ & $\geq 1600$ & $\begin{array}{l}1200- \\
1599\end{array}$ & $\begin{array}{l}800- \\
1199\end{array}$ & $<800$ \\
\hline Score & 0 & 1 & 2 & 3 \\
\hline $\begin{array}{l}\text { Total } \\
\text { cholesterol } \\
\text { (mg/dL) }\end{array}$ & $>180$ & $\begin{array}{l}140- \\
180\end{array}$ & $\begin{array}{l}100- \\
139\end{array}$ & $<100$ \\
\hline Score & 0 & 1 & 2 & 3 \\
\hline $\begin{array}{l}\text { CONUT } \\
\text { score (total) }\end{array}$ & $0-1$ & $2-4$ & $5-8$ & $9-12$ \\
\hline Assessment & Normal & Light & $\begin{array}{l}\text { Modera } \\
\text { te }\end{array}$ & Severe \\
\hline
\end{tabular}

CONUT: controlling nutritional status

In addition, patients with hematological disease or malignancy, chronic liver failure, autoimmune disease, and rheumatological disease history were excluded from the study because they could label objective nutritional indexes. The drugs used by patients were recorded from the national insurance 
system. Those who had a history of using steriod or anti-lipidemic drugs were also excluded from the study. 280 patients were evaluated for the study and 187 patients who met the inclusion criteria were included.

The CONUT and PNI scores were calculated using the laboratory results. The analyses were based on survival and in-hospital mortality; therefore, the cases were dichotomized into mortality and non-mortality groups accordingly.

Heart failure was defined as having left ventricular ejection fraction $<40 \%$. HT was defined as having a previous diagnosis of HT, systolic and diastolic blood pressure $>140 / 90 \mathrm{mmHg}$, or being on antihypertensive medication. DM was defined as having a previous DM diagnosis, using an anti-diabetic medication, fasting blood glucose $\geq 126 \mathrm{mg} / \mathrm{dL}$ or HbA1c $>6.5 \%$. Smoking was defined as having one or more cigarettes a day continuously in the last twelve months. The body mass index (BMI) was calculated by the weight/height $\left(\mathrm{m}^{2}\right)$ formula with the weight and height measurements taken on the day of hospitalization. The eGFR was calculated using the Cockcroft-Gault formula with the laboratory data results obtained from the samples taken on the day of hospitalization.

\section{Evaluation of the nutrition status of patients}

The nutritional status of the patients was determined of the objective nutritional indexes CONUT and PNI. The parameters of the CONUT score and the formula of the PNI was shown below.

\section{Prognostic nutritional index}

The PNI was calculated as an indicator of nutritional status using the formula: PNI $=10 \mathrm{x}$ serum albumin $(\mathrm{g} / \mathrm{dL})+0.005 \mathrm{x}$ total lymphocyte count $\left(\text { per } \mathrm{mm}^{3}\right)^{18}$.

\section{Controlling the nutritional status score}

CONUT scores were determined according to the Table $1^{19}$.

\section{Statistical analysis}

Levene test was used to determine whether continues variables were homogeneously distributed. Variable with normal distribution were expressed as mean \pm standard deviation, compared with Student's t-test. Also, variable with non-normal distribution were expressed as median and interquartile range (IQR) and compared with Mann-Whitney $U$ test.
Categorical variables were presented as total number and percentages and compared using the Chi-square test or Fisher exact test. Multivariate analysis using logistic regression models tested variables with $\mathrm{p} \leq$ 0.05 in univariate analysis. For each objective nutritional index two different multivariate logistic regression analysis models were established.

To demonstrate sensitivity and specificity of the PNI and CONUT scores and their cut-off values for predicting in hospital mortality Receiver Operating Characteristics (ROC) curves were used. The area under the curve (AUC) comparison of PNI and CONUT was performed by the DeLong method 20 . A two-tailed $\mathrm{p}$-value $<0.05$ was considered as statistically significant, and $95 \%$ confidence interval (95\% CIs) were presented for all odds ratios. All statistical analyses were performed using SPSS Windows software (ver. 16.0; IBM, NY, USA).

\section{RESULTS}

The study included 187 patients (mean age $66.2 \pm 1.8$ years $(55.3 \%$ male) included to the study. There were 39 deaths (mortality group), and the remaining 148 patients were discharged from the hospital (nonmortality group). Baseline clinical and demographic characteristics of patients were summarized in Table2. There were no significant differences between groups in terms of baseline characteristics, excluding the respiratory rate per minute, significantly higher in the mortality group. The laboratory parameters at the time of hospitalization were presented in Table- 2 . The mortality group had higher median AST, LDH, D-dimer, ferritin, procalcitonin, troponin, INR, and prothrombin time values, with lower serum albumin and lymphocyte count (for all $\mathrm{p}<0.05$ ). The median PNI was significantly lower and the median CONUT score was significantly higher in the mortality group (Table-2).Figure 1 shows the ROC curve analysis of the objective nutritional indexes. To predict mortality; the cut-off value of the PNI was $\leq 33$, with 97.4\% sensitivity and $58.1 \%$ specificity (AUC: 0.845 ; 95\% CI: $0.785-0.894 ; p<0.001)$ and the cut-off value of the CONUT score was $>8$, with $79.4 \%$ sensitivity and $86.4 \%$ specificity (AUC: 0.889 ; $95 \% \mathrm{CI}: 0.835-$ $0.930 ; p<0.001)$. Pairwise comparison of the ROC curve analyses has shown that the CONUT score had a better performance than PNI to predict in-hospital mortality. 
Table 2. Basal demographic, clinical characteristics, laboratory parameters and nutritional status indexes of the study groups

\begin{tabular}{|c|c|c|c|}
\hline Variables & Non-mortality $(n=148)$ & Mortality $(n=39)$ & P value \\
\hline Age, years & $65.5 \pm 16.3$ & $69.0 \pm 13.7$ & 0.226 \\
\hline Weight, $\mathrm{kg}$ & $76.0 \pm 16.0$ & $76.8 \pm 19.6$ & 0.779 \\
\hline Height, cm & $167.1 \pm 7.8$ & $168.8 \pm 8.3$ & 0.248 \\
\hline Body mass index $\left(\mathrm{kg} / \mathrm{m}^{2}\right)$ & $27.0 \pm 5.6$ & $27.5 \pm 7.8$ & 0.673 \\
\hline Gender, male, $\mathrm{n}(\%)$ & $81(54.3)$ & $23(58.9)$ & 0.606 \\
\hline Hypertension, $\mathrm{n}(\%)$ & $43(28.8)$ & $10(25.6)$ & 0.830 \\
\hline Diabetes mellitus, $\mathrm{n}(\%)$ & $43(28.8)$ & $8(20.5)$ & 0.590 \\
\hline Heart failure, $\mathrm{n}(\%)$ & $35(23.4)$ & $8(20.5)$ & 0.895 \\
\hline Coronary artery disease, $\mathrm{n}(\%)$ & $41(27.5)$ & $12(30.7)$ & 0.273 \\
\hline Chronic kidney disease, $\mathrm{n}(\%)$ & $27(18.1)$ & $5(12.8)$ & 0.169 \\
\hline Chronic obstructive pulmonary disease, $\mathrm{n}(\%)$ & $32(21.4)$ & $7(17.9)$ & 0.983 \\
\hline Cerebrovascular disease, $\mathrm{n}(\%)$ & $13(8.7)$ & $3(7.6)$ & 0.930 \\
\hline Malignancy, $\mathrm{n}(\%)$ & $14(9.3)$ & $5(12.8)$ & 0.340 \\
\hline Smoker, n (\%) & $31(20.8)$ & $9(23.0)$ & 0.384 \\
\hline Heart rate, bpm & $80.4 \pm 14.3$ & $79.4 \pm 17.1$ & 0.752 \\
\hline Systolic blood pressure, $\mathrm{mm} \mathrm{Hg}$ & $118.0 \pm 18.5$ & $124.2 \pm 20.0$ & 0.118 \\
\hline Diastolic blood pressure, $\mathrm{mm} \mathrm{Hg}$ & $72.0 \pm 13.0$ & $73.0 \pm 12.1$ & 0.715 \\
\hline $\mathrm{O}_{2}$ saturation, $\%$ & $84.5 \pm 9.0$ & $83.2 \pm 9.1$ & 0.498 \\
\hline Respiratory rate, $\mathrm{rpm}$ & $18.4 \pm 3.7$ & $19.9 \pm 3.3$ & 0.045 \\
\hline Body temperature, ${ }^{\circ} \mathrm{C}$ & $36.9 \pm 0.8$ & $37.4 \pm 1.2$ & 0.075 \\
\hline Glucose, $\mathrm{mg} / \mathrm{dL}$ & $123(97)$ & $151(82,5)$ & 0.545 \\
\hline Creatinine, $\mathrm{mg} / \mathrm{dL}$ & $1.63 \pm 1.86$ & $1.63 \pm 0.91$ & 0.992 \\
\hline Uric acid, $\mathrm{mg} / \mathrm{dL}$ & $5.71 \pm 2.50$ & $5.92 \pm 2.53$ & 0.677 \\
\hline $\mathrm{eGFR}, \mathrm{ml} / \mathrm{m} / 1.73$ & $66(53)$ & $58(52,5)$ & 0.054 \\
\hline Albümin, $\mathrm{g} / \mathrm{dL}$ & $30.30 \pm 7.61$ & $22.14 \pm 5.33$ & $<0.001$ \\
\hline Total protein, $\mathrm{g} / \mathrm{dL}$ & $6.48 \pm 1.25$ & $5.42 \pm 1.38$ & $<0.001$ \\
\hline AST, U/L & $22(26)$ & $48(92)$ & $<0.001$ \\
\hline $\mathrm{ALT}, \mathrm{U} / \mathrm{L}$ & $22(15)$ & $35(67.5)$ & $<0.001$ \\
\hline $\mathrm{LDH}, \mathrm{U} / \mathrm{L}$ & $260(175)$ & $444(442)$ & $<0.001$ \\
\hline Total cholesterol, $\mathrm{mg} / \mathrm{dL}$ & $181(63.4)$ & $157.5(40)$ & 0.024 \\
\hline $\mathrm{LDL}, \mathrm{mg} / \mathrm{dL}$ & $118(52)$ & $110(38)$ & 0.197 \\
\hline $\mathrm{HDL}, \mathrm{mg} / \mathrm{dL}$ & $36(16)$ & $33(15.2)$ & 0.040 \\
\hline WBC, $10^{3} / \mu \mathrm{L}$ & $10.4(5.6)$ & $11.5(9.2)$ & 0.077 \\
\hline Platelets, $10^{3} / \mathrm{mL}$ & $237(163)$ & $216(146)$ & 0.924 \\
\hline Lymphocyte, $10^{3} / \mu \mathrm{L}$ & $1000(900)$ & $300(300)$ & $<0.001$ \\
\hline Neutrophil, $10^{3} / \mu \mathrm{L}$ & $7.2(0.5)$ & $9.7(0.9)$ & 0.006 \\
\hline $\mathrm{CRP}, \mathrm{mg} / \mathrm{L}$ & $3.3(99.9)$ & $11.9(190)$ & 0.002 \\
\hline D-DIMER, ng/mL & $1240(2467)$ & $3765(17200)$ & $<0.001$ \\
\hline Ferritin, $\mu \mathrm{g} / \mathrm{L}$ & $164(376.8)$ & $378.9(1910.1)$ & 0.001 \\
\hline Procalcitonin, $\mu \mathrm{g} / \mathrm{L}$ & $0.26(0.8)$ & $2.9(4.3)$ & 0.004 \\
\hline Troponin I, ng/L & $70(165)$ & $285(1666)$ & $<0.001$ \\
\hline INR & $1.1(0.3)$ & $1.4(0.7)$ & 0.003 \\
\hline Prothrombin time, $\mathrm{s}$ & $14(4.9)$ & $18.4(8.9)$ & 0.004 \\
\hline Fibrinogen, $\mathrm{mg} / \mathrm{dL}$ & $400(224)$ & $432(392)$ & 0.359 \\
\hline $\mathrm{BNP}, \mu \mathrm{g} / \mathrm{L}$ & $1500(6983)$ & $21250(18600)$ & 0.217 \\
\hline PNI, median (IQR) & $36.05(15.42)$ & $23.50(8.25)$ & $<0.001$ \\
\hline CONUT, median (IQR) & $4.0(5.0)$ & $9.0(1.0)$ & $<0.001$ \\
\hline
\end{tabular}

AST: aspartate aminotransferase; ALT: alanine aminotransferase; LDH: lactate dehydrogenase; WBC: white blood cell; INR: international normalized ratio; CONUT: controlling nutritional status; PNI: prognostic nutritional index; BNP: brain natriuretic peptide; CRP: C reactive protein; eGFR: estimated glomerular filtration rate; HDL-C: high density lipoprotein cholesterol; LDL-C: low density lipoprotein cholesterol 


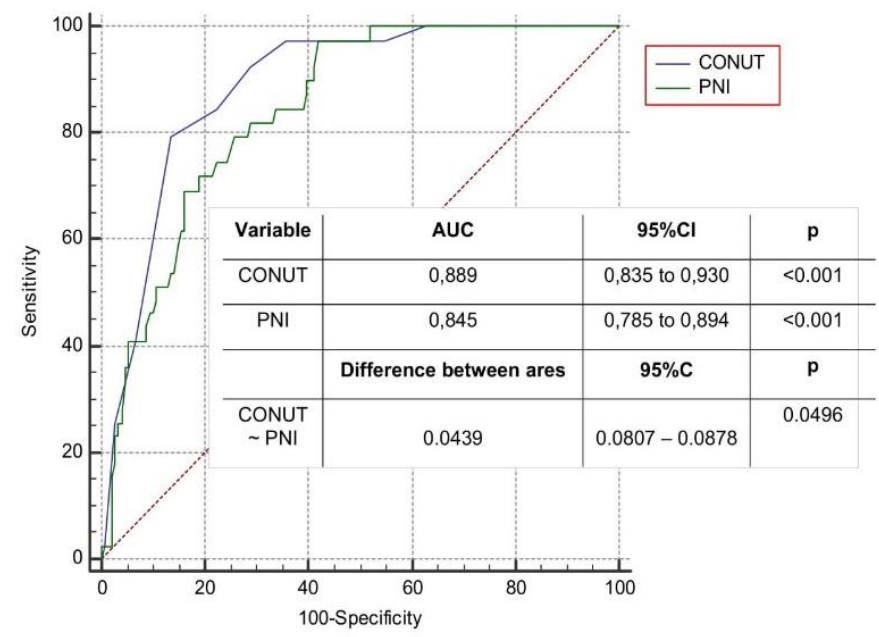

Figure 1. Comparison of the ROC curves of CONUT and PNI for in-hospital mortality

ROC: receiver operating characteristic, CONUT: controlling nutritional status PNI: prognostic nutritional index, AUC: area under curve, $\mathrm{CI}$ : confidence interval

Table 3. Univariate and multivariate logistic regression analysis for mortality

\begin{tabular}{|l|l|c|c|c|c|c|}
\hline & \multicolumn{3}{|c|}{ Univariate logistic regression analysis } & \multicolumn{3}{c|}{ Multivariate logistic regression analysis } \\
\hline & OR & $\begin{array}{c}\mathbf{9 5} \text { \% CIs } \\
\text { (confidence interval) }\end{array}$ & p value & OR & $\begin{array}{c}\text { 95 \% CIs } \\
\text { (confidence } \\
\text { interval) }\end{array}$ & p value \\
\hline Albumin & 0.179 & $0.092-0.347$ & $<0.001$ & & & \\
\hline Total protein & 0.540 & $0.381-0.766$ & 0.001 & & & \\
\hline AST & 1.008 & $1.003-1.013$ & 0.002 & & & \\
\hline ALT & 1.006 & $1.000-1.011$ & 0.041 & & & $\mathbf{0 . 0 1 0}$ \\
\hline LDH & 1.003 & $1.001-1.005$ & 0.001 & 1.003 & $1.001-1.006$ & \\
\hline Total cholesterol & 0.991 & $9.983-0.999$ & 0.026 & & & $<.001$ \\
\hline HDL & 0.965 & $0.931-0.999$ & 0.043 & & & \\
\hline Lymphocyte & 0.997 & $0.996-0.998$ & $<0.001$ & 0.997 & $0.995-0.999$ & \\
\hline Neutrophil & 1.000 & $1.000-1.000$ & 0.009 & & & \\
\hline CRP & 1.008 & $1.004-1.013$ & $<0.001$ & & & \\
\hline Procalcitonin & 1.172 & $1.042-1.318$ & 0.008 & & & \\
\hline D-Dimer & 1.000 & $1.000-1.000$ & 0.004 & & & \\
\hline Ferritin & 1.000 & $1.000-1.001$ & 0.007 & & & \\
\hline Troponin & 1.000 & $1.000-1.000$ & 0.030 & & & \\
\hline INR & 2.060 & $1.110-3.824$ & 0.022 & & & $\mathbf{0 . 0 0 3}$ \\
\hline Pro-thrombin time & 1.039 & $1.003-1.077$ & 0.034 & & & $\mathbf{0 . 0 2 7}$ \\
\hline Respiratory rate & 1.119 & $1.001-1.250$ & 0.048 & & & \\
\hline CONUT* & 1.849 & $1.493-2.290$ & $<0.001$ & 2.361 & $1.351-4.128$ & \\
\hline PNI** & 0.832 & $0.779-0.890$ & $<0.001$ & 0.829 & $0.703-0.979$ & \\
\hline
\end{tabular}

*Model-1 included AST, ALT, LDH, HDL-C, Neutrophil, Lymphocyte, CRP, Procalcitonin, D-Dimer, Ferritin, Troponin, Prothrombin time, Respiratuvar rate.

**Model-2 included, AST, ALT, LDH, HDL-C, Neutrophil, , Lymphocyte, CRP, Procalcitonin, D-Dimer, Total cholesterol, Ferritin,

Troponin, Pro-thrombin time, Respiratuvar rate. 
Two different multivariate regression analysis models have shown that both PNI (OR: 0.829; 95\% CI: $0.703-0.979 ; p=0.027$ ) and CONUT score (OR: 2.361; 95\% CI:1.351-4.128; $\quad p=0.003) \quad$ were independently associated with in-hospital mortality. Other independent predictors of in-hospital mortality were LDH and lymphocyte count (Table-3).

\section{DISCUSSION}

The study revealed a significant association of the nutritional condition of the COVID-19 patients hospitalized in ICUs with in-hospital mortality. The results indicated that CONUT and PNI scores were independent predictors for in-hospital mortality, with CONUT presenting a better performance than PNI.

To our knowledge, there are no studies available that have evaluated the association of the nutritional condition of COVID-19 patients with in-hospital mortality.

Acute respiratory failure and multiple organ failure are the most common causes of ICU admissions in COVID-19 patients. Due to the lack of specific treatment, treatment in COVID-19 patients consists of relief of symptoms and support of the deteriorating organ. Although many risk factors and laboratory parameters have been shown in the prediction of patients in need of ICU, it is still not possible to predict which patients may have ICU and may be mortal. In this respect, it is important that we show that poor nutritional status of patients is a predictor of mortality in our study.

Malnutrition is a significant health problem observed in hospitalized patients ${ }^{21}$. The incidence varies between $13-86 \%$ in acute care patients, $42-91 \%$ in elderly patients, and $4-90 \%$ in special patient groups such as acute myocardial infarction, chronic kidney failure, malignancies, and patients with acute respiratory distress syndrome 22 .

The objective nutritional indexes are calculated using simple formulas and associated with mortality in various diseases, including cardiac and liver failure, hypertension, and malignancies ${ }^{23}$.

Numerous laboratory parameters and risk factors have been determined in COVID-19 patients for mortality remaining a lot more waiting to be uncovered. Determination of the poor nutritional status of a COVID-19 patient on hospitalization might help to predict undesired outcomes. The study showed that the PNI score, easy to use, calculated by lymphocyte count and serum albumin level, performed well in predicting the in-hospital mortality rates of ICU patients with COVID-19. The low PNI scores, indicating a poor nutritional status, were associated with high mortality in COVID-19 patients, similar to the associations computed in other diseases. In previous studies, the components of the PNI, low lymphocyte count, and low serum albumin levels were shown to be associated with worse outcomes separately ${ }^{24}$. In this study, we have shown that the PNI index, which includes both parameters in the calculation, was associated with worse outcomes. The multivariant regression analyses have shown that PNI independently associated with inhospital mortality. Moreover, our results revealed that the CONUT score was an independent predictor of in-hospital mortality for ICU patients with COVID-19. Besides, compared to PNI, CONUT presented a better performance in predicting inhospital mortality. CONUT score can accurately reflect the nutritional status and immune function of the body. As the CONUT score increases, the severity of malnutrition also increases, indicating a poor prognosis for most chronic diseases. The parameters used to determine the CONUT score, similar to the PNI, include the lymphocyte count and serum albumin levels. The difference is that the serum cholesterol levels exist in the calculation of the CONUT score. The low mean cholesterol level contributes to the better performance of the CONUT score over PNI in predicting mortality. Parallel to a study conducted in China, suggesting that COVID-19 patients had lower serum cholesterol levels than healthy controls ${ }^{25}$. Moreover, a recent study from Spain showed that low serum cholesterol levels are associated with 30-day mortality in COVID-19 patients $^{26}$.

As shown in previous studies, in our study, it was shown that lymphocyte count was significantly low and independently associated with mortality. In addition, parameters such as CRP, ferritin and D dimer, Troponin, AST, ALT, fibrinogen and prothrombin time, which were shown to be mortality predictors in many previous studies, lost their significance in multivariate analysis, although they were different between the groups in our study. This may be due to the fact that all of the patients included in our study were high-risk patients. In addition, it can be interpreted that the importance of these parameters decreases when nutritional indexes are used together with laboratory parameters in these patients. However, larger studies will guide this. 
In our study, surprisingly, LDH was identified as an independent risk factor for mortality. In previous studies, it has been shown that increased LDH is associated with severe lung involvement in lung involvement secondary to viral diseases ${ }^{27,28}$. Our study also supports that the increased $\mathrm{LDH}$ in the patient group who died can be used as an indicator of a more serious lung injury.

One major limitation was the small sample size. Also, it was a single-center study. The study included severe ICU patients with COVID-19 diagnosis. Thus, the study results should not be generalized for all COVID-19 patients. Studies with larger samples are required to confirm our results.

The study revealed a significant association of the nutritional condition of the COVID-19 patients hospitalized in ICUs with in-hospital mortality. The results indicated that CONUT and PNI scores were independent predictors of in-hospital mortality, with CONUT presenting a better performance than PNI. To the best of our knowledge, our study is the first to evaluate PNI and CONUT indexes and compare among patients with COVID-19.

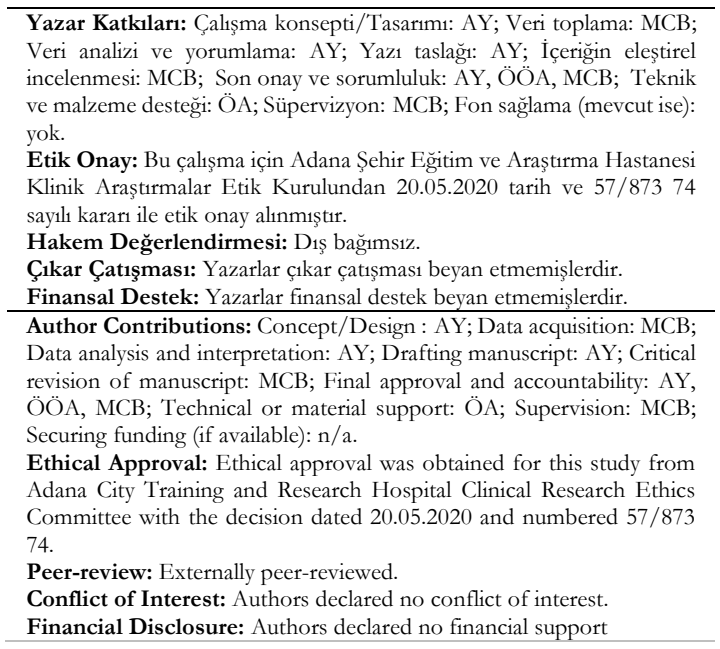

\section{REFERENCES}

1. Lai CC, Shih TP, Ko WC,Tang HJ, Hsueh PR. Severe acute respiratory syndrome coronavirus 2(SARSCoV-2) and corona virus disease-2019 (COVID-19): the epidemic and the challenges. Int $\mathrm{J}$ Antimicrob Agents. 2020;55:105924.

2. Wang D, Hu B, Hu C, Zhu F, Liu X, Zhang J et al. Clinical characteristics of 138 hospitalized patients with 2019 novel coronavirus-infected pneumonia in Wuhan,China. JAMA. 2020;323:1061-9.
3. Lima CMAdO. Information about the new coronavirus disease(COVID-19). Radiol Bras. 2020;53:V-VI.

4. Cascella M, Rajnik M, Cuomo A, Dulebohn SC, Di Napoli R. Features, evaluation and treatment coronavirus (COVID-19). In StatPearls [Internet].Treasure Island (FL), StatPearls Publishing, 2021

5. Guan WJ, Ni ZY, Hu Y, Liang WH, Ou CQ, He JX et al. Clinical characteristics of coronavirus disease 2019 in China. N Engl J Med. 2020;382:1708-20.

6. Kinross P, Suetens C, Dias JG, Alexakis L, Wijermans A, Colzani E et al.Rapidly increasing cumulative incidence of coronavirus disease(COVID-19) in the European Union/European Economic Area and the United Kingdom, 1 January-15 March 2020. Euro Surveill. 2020;25:2000285.

7. COVID TC, Team R. Severe outcomes among patients with coronavirus disease-2019 (COVID-19)United States,February 12-March 16,2020. MMWR Morb Mortal Wkly Rep. 2020;69:343-6.

8. Han H, Xie L, Liu R, Yang J, Liu F, Wu K et al. Analysis of heart injury laboratory parameters in 273 COVID-19 patients in one hospital in Wuhan,China. J Med Virol. 2020;92:819-23.

9. Paterson RW, Brown RL, Benjamin L, Nortley R, Wiethoff S, Bharucha $\mathrm{T}$ et al.The emerging spectrum of COVID-19 neurology:clinical, radiological and laboratory findings. Brain. 2020;143:3104-20.

10. Mardani R, Vasmehjani AA, Zali F, Gholami A, Nasab SDM, Kaghazian $\mathrm{H}$ et al. Laboratory parameters in detection of COVID-19 patients with positive RT-PCR;a diagnostic accuracy study. Arch Acad Emerg Med. 2020;8:e43.

11. Wu T, Zuo Z, Kang S, Jiang L, Luo X, Xia Z et al. Multi-organ dysfunction in patients with COVID-19: A systematic review and meta-analysis. Aging Dis. 2020;11:874-94.

12. Thachil J, Tang N, Gando S, Falanga A, Cattaneo M, Levi $\mathrm{M}$ et al. ISTH interim guidance on recognition and management of coagulopathy in COVID-19. J Thromb Haemost. 2020;18:1023-6.

13. Abou-Ismail MY, Diamond A, Kapoor S, Arafah Y, Nayak L. The hypercoagulable state in COVID19:Incidence, pathophysiology, and management. Thromb Res. 2020;194:101-5.

14. Trevisan C, Crippa A, Ek S, Welmer A-K, Sergi G, Maggi $S$ et al. Nutritional status, body mass index,and the risk of falls in community-dwelling older adults:a systematic review and meta-analysis. J Am Med Dir Assoc. 2019;20:569-82.e7.

15. Sun G, Li Y, Peng Y, Lu D, Zhang F, Cui X et al. Impact of the preoperative prognostic nutritional index on postoperative and survival outcomes in colorectal cancer patients who underwent primary tumor resection:a systematic review and metaanalysis. Int J Colorectal Dis. 2019;34:681-9. 
16. Li J, Xu R, Hu DM,Zhang Y, Gong TP, Wu XL. Prognostic nutritional index predicts outcomes of patients after gastrectomy for cancer:a systematic review and meta-analysis of nonrandomized studies. Nutr Cancer. 2019;71:557-68.

17. Tao AI, Yang Z, Hou H, Zhan C, Chen C, Lv W et al. Correlation of chest CT and RT-pcr testing for coronavirus disease 2019(COVID-19) in China:A report of 1014 cases. Radiology. 2020;296:E32-40.

18. Agus HZ, Kahraman S. Prognostic nutritional index predicts one-year outcome in heart failure with preserved ejection fraction. Acta Cardiol. 2020;75:450-5.

19. Sun X, Luo L, Zhao X, Ye P. Controlling Nutritional Status(CONUT) score as a predictor of all-cause mortality in elderly hypertensive patients: a prospective follow-up study. BMJ Open. 2017;7:e15649.

20. DeLong ER, DeLong ED, Clarke-Pearson DL. Comparing the areas under two or more correlated receiver operating characteristic curves: a nonparametric approach. Biometrics, 1988;44:837-45

21. Lew CCH, Yandell R, Fraser RJ, Chua AP, Chong MFF, Miller M. Association between malnutrition and clinical outcomes in the intensive care unit: a systematic review. JPEN J Parenter Enteral Nutr. 2017;41:744-58.

22. Barker LA, Gout BS, Crowe TC. Hospital malnutrition:prevalence, identification and impact on patients and the healthcare system. Int J Environ Res Public Health. 2011;8:514-27.

23. Narumi T, Arimoto T, Funayama A, Kadowaki S, Otaki Y, Nishiyama S et al. The prognostic importance of objective nutritional indexes in patients with chronic heart failure. J Cardiol. 2013;62:307-13.

24. Huang W, Li C, Wang Z, Wang H, Zhou N, Jiang J et al. Decreased serum albumin level indicates poor prognosis of COVID-19 patients:hepatic injury analysis from 2,623 hospitalized cases. Sci China Life Sci. 2020;63:1678-87.

25. Hu X, Chen D, Wu L, He G, Ye W. Declined serum high density lipoprotein cholesterol is associated with the severity of COVID-19 infection. Clin Chim Acta. 2020;510:105-10.

26. Aparisi A, Echeverría CI, Falcón CY, Cusácovich I et al. Low-density lipoprotein cholesterol levels are associated with poor clinical outcomes in COVID-19. medRxiv. doi: 10.1101/2020.10.06.20207092.

27. Mo X, Wei F, Tong Y, Ding L, Zhu Q, Du S et al. Lactic acid downregulates viral MicroRNA to promote epstein-barr virus-immortalized B lymphoblastic cell adhesion and growth. J Virol. 2018;92:e00033-18.

28. Calderón EJ, Gutiérrez-Rivero S, Durand-Joly I, DeiCas E. Pneumocystis infection in humans:diagnosis and treatment. Expert Rev Anti Infect Ther. 2010;8:683-701. 